\title{
A MESTERSÉGES NEURÁLIS HÁLÓZATOK ALKALMAZÁSÁNAK LEHETŐSÉGEI A BIOMETRIKUS SZEMÉLYAZONOSÍTÁSBAN
}

\section{ADAPTATION OF ARTIFICIAL NEURAL NETWORKS IN BIOMETRICS}

\author{
Werner Gábor ${ }^{1}$, Hanka László ${ }^{2}$ \\ I'́budai egyetem, Biztonságtudományi Doktori Iskola, 1034 Magyarország, Buda- \\ pest, Bécsi út 96./b; +36 (1) 666-5375,wga.bme@gmail.com \\ ${ }^{2}$ Óbudai Egyetem, Mechatronikai és Autótechnikai Intézet, 1081 Magyarország, Bu- \\ dapest, Népszínház utca 8.; +36(1)-666-5322, hanka.laszlo@bgk.uni-obuda.hu
}

\begin{abstract}
In this study we have presented a simplified solution of an artificial neural network which is matching the patterns of biometrical templates. It was shown how an artificial neural network built up and how it works. We gave a manual instruction step-by-step of our algorithm's procedure, and we highlighted the mayor difficulties and traps that we experienced.

Keywords: biometrics, artificial intelligence, artificial neural network.

\section{Összefoglalás}

Cikkünkben a mesterséges neurális hálózatok biometriában történő alkalmazhatóságát vizsgáltuk. Bemutattuk, hogy a mesterséges neurális hálók hogyan épülnek fel, mi adja müködésük alapját és milyen problémák megoldására alkalmazhatóak. Egy általános, de plasztikus leírással pontról pontra ismertetjük az általunk alkalmazott algoritmus müködését, felkeltve az olvasó figyelmét azokra a nehézségekre amiket mi is megtapasztaltunk.
\end{abstract}

Kulcsszavak: biometria, mesterséges intelligencia, mesterséges neurális hálózat.

\section{Bevezetés}

A biometrikus azonosításban nehézségeket okoz, hogy a beolvasott minták jelentős eltérést mutathatnak a tárolt sablonokhoz képest. Ennek következtében sok esetben az eredeti biometrikus mintát is imposztornak érzékelheti az azonosítóeszköz.

Amennyiben megvizsgáljuk ezen eltérések lehetséges okait, akkor több tényezőt is megemlíthetünk, amelyek mind befolyásolják a biometrikus mintázatot. A konvencionális biometrikus vizsgálat során az azonosítandó személy valamilyen egyedi biológiai sajátosságát vizsgálva azonosítjuk az identitást. Ez a sajátos jegy azonban nem tekinthető permanensnek. Függően az adott biometrikus azonosítási módszertől, a mintázat beolvashatóságát erősen befolyásolhatja az időjárás, a helyi környezeti viszonyok (fény, páratartalom, por, stb.), az azonosítandó személy lelki és fiziológiai állapota, valamint az eszköz és a felhasználó közti ember-gép kapcsolat (az azonosítandó személy ismeri-e, tudja-e kezelni az eszközt, a telepítés megfelelö-e az ergonómiai szempontoknak, stb.) [1].

A biometrikus azonosító eszközök vezérlése többnyire a konvencionális matematikát, módszereket alkalmazza. A lineáris 
matematikai megoldások viszont nehezen képesek megfelelni a fent említett gyors változásoknak. Ennek fényében, e cikkben azt vizsgáltuk, hogy miként alkalmazhatóak a mesterséges intelligenciát megtestesítő lágy számítási módszerek közé sorolt mesterséges neurális hálózatok.

\subsection{A mesterséges neurális hálózatok rövid ismertetése}

A mesterséges neurális hálózatok (továbbiakban $\mathrm{ANN}$ ) az emberi agy biológiai sajátosságain alapulnak. Struktúrájukat alapvetően a csomópontok (mesterséges neuronok, vagy perceptronok) és az ezeket bizonyos értékkel súlyozott összeköttetések jellemzik [2].

A szerkezetüket tekintve a legfontosabb sajátosság, hogy - ellentétben biológiai formájukkal - a perceptronok rétegekbe rendeződnek, és minden réteg csak a szomszédos rétegekkel állhat kapcsolatban. A kapcsolatok erősségét jellemző súlyokat kezdetben egy véletlenül generált szám jellemzi, ami az úgynevezett tanulási fázisban módosul. A hálózat súlyai a tréning alatt akként módosulnak, hogy a legjobban illeszkedő kimeneti értéket kapjuk. A súlyokat több módszer szerint is lehet módosítani az egyik legeleterjedtebb és általunk is vizsgált megoldás az úgynevezett hibavisszaterjesztéses elörecsatolás (feedforward back-propagation) [3].

$\mathrm{Az}$ ANN méretét és rétegeinek számát alapvetően a megoldandó probléma összetettsége határozza meg. A perceptronok számának növelésével azonban exponenciálisan növekszik az elvégezendő matematikai müveletek száma, így a bonyolultabb feladatok nagyobb számítási kapacitás igényel.

\subsection{A biometrikus minták kinyerése}

A biometrikus azonosító eszközök minden esetben valamilyen módon előfeldolgozzák, majd kinyerik a jellemző kódsort a beolvasott biometrikus mintákból.
A beolvasás módja a biometrikus azonosítás típusán belül is változhat, ahogy a kinyert sajátos információk pontos jellemzői is. A legtöbb esetben valamilyen optikai szenzorral érzékelhető geometriai mintázat kerül beolvasásra, de esetenként hang vagy más dinamikus jellemző is detektálható, bár ezek a technológiák kisebb szelektivitást biztosítanak jelenleg.

A szerzett mintázat előfeldolgozása után következik a sajátosságok kinyerése, azaz az egyedi azonosító jegyek dekódolása. A piacon forgalomban lévő eszközökbe sokféle technikát fejlesztettek, de a legtöbb módszer azon alapul, hogy a mintázatban szereplő karakterisztikus jegyeket felismerje és azonosítsa geometriai pozícióját (távolságok, szögek, formák, stb.) [4].

\subsection{A mintázatok összehasonlításának problémái}

A biometrikus azonosítás komplex problémája a mintázatok összevetése (pattern matching), mert az egyedi azonosító jegyekből kinyert információ több feltételnek együttesen kell, hogy megfeleljen.

Egyfelől biztosítani kell a kellő szelektivitást, másfelől a kinyert értékeket úgy kell meghatározni, hogy azok reprodukálhatóak legyenek, harmadrészröl pedig figyelembe kell venni az időtényezőt, hiszen a feldolgozás kapacitása véges.

$\mathrm{Az}$ első szempont általában meghatározza, hogy egy adott biometrikus módszernél mennyi és milyen egyedi azonosítójegyből kinyert adatra van szükség. Az időtényezó általában ezzel ellentétes igényeket támaszt, mert az egyedi azonosító jegyek számának növekedésével a feldolgozás ideje exponenciálisan növekszik. E tanulmány szempontjából a második szempont jelenti a legnagyobb kihívást, egyebek között azért, mert implicite hatással van a másik két feltétel optimalizálására.

A tapasztalatok azt mutatják, hogy amennyiben két biometrikus minta tökéletesen azonos, akkor az egyik vélhetően ha- 
mis. Ennek következtében az algoritmusok mindig megengednek bizonyos hibatürést, habár ez hátrányosan befolyásolja a szelektivitást. Ennek az ellentétnek tudható be, hogy a biometrikus eszközök vizsgálatára széles körben alkalmazott FAR (hibás elfogadás aránya) és FRR (hibás visszautasítás aránya) értékek egymáshoz képest egy hiperbolikus függvény mentén változnak, eszköz-specifikusan [5].

Ennek megfelelően a biometrikus mintázatok összehasonlítása kapcsán az volt a célunk, hogy a szelektivitás megtartása mellett nagyobb hibatürést biztosítsunk. A vizsgálatok alapján ennek biztosítására konvencionális, lineáris módszerekkel szemben - az ANN jól alkalmazható.

\section{A mesterséges neurális hálóza- tok alkalmazása}

A mesterséges neurális hálók alkalmazása olyan feladatok megoldásánál indokolt, ahol egy összetett, analitikusan nem, vagy csak rossz hatásfokkal elemezhető mintázatot kell azonosítani. A biometrikus minták szinte minden típusában olyan komplex mintázatot kell elemezni, amit folytonos, de nem állandó értékű hibák terhelnek, így az ANN alkalmazása a biometria teljes skálájára kiterjeszthető.

Az ANN képes megoldani nem-lineáris matematikai problémákat, és a megfelelő tanítás után képes gyors és pontos következtetések megállapítására [6].

\subsection{Az alkalmazás folyamata}

A mesterséges neurális hálók alkalmazása során körültekintően kell eljárnunk. Sokféle biometrikus minta felismerését és azonosítását vagyunk képesek megoldani, ha a szükségszerü lépéseket betartjuk és megfelelően választjuk meg a beállításokat.

\subsubsection{Probléma vizsgálata ANN szem- pontból}

Első lépésként fontos, hogy kiderítsük a megoldandó probléma jellegét. Léteznek olyan minta felismerési problémák, amelyek nem feltétlenül igénylik az ANN használatát. Ilyen lehet többek között például a biometrikus érzékelőkbe épített élőminta azonosítás.

\subsubsection{Információ kinyerése}

Az egyik jelentős probléma az ANN biometriában történő alkalmazása során a vizsgálandó információ egzakt meghatározása. Az ANN bemeneti rétegére olyan információ halmazt (bemeneti vektort) kell generálni, ami tükrözi az minta egyediségét, pontosan mérhető és kellően toleráns a fellépő hibákkal szemben, figyelembe véve az időtényező jelentőségét is.

A legtöbb biometrikus azonosítóeszköz az egyedi azonosítójegyek mátrixának detektálásán alapul. Az azonosítójegyek térbeli vagy síkbeli elrendezése határozza meg tulajdonképpen a bemeneti vektort. A biometrikus minta típusa determinálja, hogy hány azonosító jegy felismerése szükséges, illetve milyen és mennyi adatra van szükség az azonosítójegyek egymáshoz képesti elhelyezkedéséről. Az eszközök nagyobb része állandó koordináta rendszerhez igazítja az egyedi azonosítójegyek geometriai elhelyezkedését, de nagyobb hibatoleranciát lehet elérni, ha a koordinátarendszert a beolvasott minta valamilyen karakterisztikus pontjához illesztjük.

\subsubsection{Tanulási folyamat}

A tanulási folyamat lényege, hogy az egymás utáni többszöri mintafelismerés és a bemeneti vektor generálás után, a bemeneti vektor részben, vagy egészben reprodukálódik. Az ANN tanulási szakaszának célja az, hogy az ismétlődő részeket könnyebben felismerhetővé tegye, mégpedig úgy, hogy az egyes beolvasások során generált bemeneti vektorokat egymás után többször küldjük át a teljes neurális hálózaton, egészen addig, amíg a kimeneti érték meg nem közelíti tetszőleges mértékkel a kívánt kimeneti értéket. Erre a célra jól alkalmazható a 
hiba-visszaterjesztéses tanítási mód, de számos más tanítási program említhető

\subsubsection{Tesztelés és validálás}

A tanítási folyamat eredményeképpen biztosítjuk, hogy a kimeneti érték a kívánt kimenetet tetszőleges megközelítse, de ez csak azokra a mintákra igaz, amelyek a tanulási sorozatban szerepeltek (1. ábra).

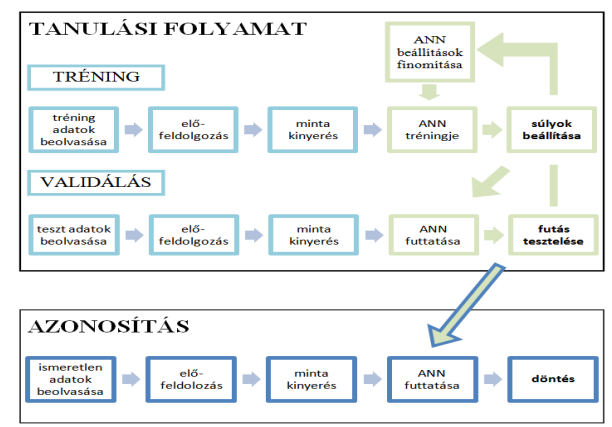

1. ábra. Az ANN tanulási folyamata

A tesztelés célja az, hogy leellenőrizzük a tanulás során beállt súlymátrix kellően érzékeny-e az ismerős mintákra, és kellően elutasító-e az imposztorokkal szemben. A teszt során egy olyan adatbázist kell betáplálni, amiben ismerjük az eredeti és az idegen mintákat. A tesztciklus futását követően kapunk egy statisztikai értéket, ami alapján eldönthető, hogy tanítás sikeres-e vagy sem. Abban az esetben, ha a kapott eredmény nem kielégítő, új tanulást kell kezdeni, vagy változtatni kell a beállításokon.

A kutatási eredményeink azt mutatták, hogy a tanulási folyamat sikerét illetően különösen fontos a kezdeti súlymátrix megfelelö generálása. Amennyiben a kezdeti súlymátrix random generátora bármilyen szimmetriát mutatott a tanulás hatásfoka lecsökkent.

\subsubsection{ANN használata}

A sikeres tanulás után validált háló már jó hatásfokkal képes a biometrikus minták azonosítására. Ezzel együtt figyelembe kell venni, hogy a legjobban tanított és ellenőr- zött háló sem képes tökéletes eredményre. Azokban az esetekben, amikor a biometrikus mintából kiolvasott egyedi azonosítójegyek jelentős mértékben változnak meg (pl.: nagymértékben roncsolódik a minta, megváltozik egy fontos környezeti körülmény) nem imposztortól származó minta is elutasításra kerülhet. Mindazonáltal az ANN beállításainak gondos megválasztásával és ellenőrzött tanulással a konvencionális megoldásoknál nagyobb hibatolerancia érhető el azonos szelektivitás mellett.

\section{Következtetések}

Eddigi eredményeink bizakodásra adnak okot, az ANN alkalmazása a biometriában mindenképpen jelentős előnnyel bír. Az ujjnyomaton túl a feltevéseink megerősítéséhez a jövőben a lehető legtöbb biometrikus azonosítási módszerrel kell elvégezni kísérletet egy nagyobb elemszámú mintán. A területen kihívást jelent a megfelelő beállítások és kezdeti súlyértékek meghatározása, így ezek optimalizálása újabb feladatokat jelöl ki.

\section{Szakirodalmi hivatkozások}

[1] Elliott, S. J., Kukula E. P., Sickler N. C.: The Challenges of the Environment and the Human / Biometric Device: Interaction on Biometric System Performance, Biometric Standards, Performance and Assurance Laboratory, Purdue University, 2002

[2] M. Hajek, Neural Networks, 2005, 6-14.

[3] Hagan M. T.: Neural Network Design, PWS Pub. Co., ISBN: 978-0534943325, 1995.

[4] Chung Chang-K. et al.: An Biometric Identification System by Extarcting Hand Vein Patterns, Journal of the Korean Physical Society, Vol. 38, No. 3. 2001.

[5] Jain, L.C., Halici, U., Hayashi, I., Lee, S. B., Tsutsui, S.: Intelligent Biometric Techniques in Fingerprint ans Face Recognition, The CRC Press International Series on Computational Intelligence, 1999, 107-193.

[6] Veer Singh, K.: Apllication of Neural Networks in Fingerprint Identification, Thapar University, Patiala, 2010, 7-8. 